\title{
THE POLITICS AND POLITICISATION OF DISABILITY
}

\section{Introduction}

On 22 May 1922, Dai Watts Morgan, MP for the Rhondda valleys in south Wales, described the bitterness felt by permanently injured miners in his constituency to his honourable colleagues in the House of Commons. He outlined in uncomfortable detail their long struggle to receive a level of compensation that allowed a decent standard of living:

In no case where [the miners] have been totally disabled for life have they received the maximum of $£ l$ a week. Such men, when they meet us from day to day or from week to week, say: 'When are you going to do something to assist us and to put our cases upon a just level, and to give us the rights that we ought to receive?' ${ }^{1}$

Watts Morgan, a former miner himself, conveyed in his speech the level of anger and injustice about disability that was felt in the coalfields. It was an impassioned contribution to the politics of disability, bringing to light both the grievances of individual miners and the wider structures of injustice that faced disabled people in the coalfields. While disability is inevitably a political issue in every chronological and cultural context in which it is found, the precise character of the politics of disability varies in time and from place to place, and it is possible to see differences in the ways in which such politics played out in the different coalfields. ${ }^{2}$ Such differences coincide with important issues within the historiography of comparative coalfield societies, which discerns different political trajectories and traditions in each of the coalfields. Differing degrees of conflict and consensus, on the one hand, and variations in change and continuity over time, on the other, meant that each coalfield in Britain possessed its own, distinct political context. ${ }^{3}$ Such distinctions and differences are just as evident in the politics of disability. More than that, it might be argued that 
disability, while always political, underwent a process of further politicisation in the period under consideration. An adversarial compensation system, initiated in 1880 and brought into full existence in 1897, pitted workers - through their trade unions - against their employers in legal contest, and led to significant amounts of time, effort and resources being expended by both sides to influence and amend legislation passed in the House of Commons. This, of course, had profound implications for the experiences of impaired miners and their families and the power relations in which they found themselves enmeshed.

Literature and disability politics are also closely interrelated in this period. Several prominent writers were ex-miners and politicians, including Scottish miner James C. Welsh MP, and Durham miners John Swan $\mathrm{MP}^{5}$ and Jack Lawson MP. ${ }^{6}$ Some contested as parliamentary candidates but were unsuccessful, such as Joseph Keating, ${ }^{7}$ Harold Heslop ${ }^{8}$ and Jack Jones. ${ }^{9}$ Many writers were involved with the Communist Party (CP), such as Lewis Jones or Jack Jones, ${ }^{10}$ or took active roles in the trade union, such as Harold Heslop or John Swan. ${ }^{11}$ The experience of disability, often connected to unemployment, was the focus of many writers, while disability metaphors were prolific in representing political solidarity, in which the strength of the people united (including those with impaired bodies) represents an embodied political strength. ${ }^{12}$

This chapter outlines the many ways that disability informed the politics of coalmining in the period from 1880 to 1948 and the myriad ways in which disability issues figured in industrial relations within the industry during this period. It uses an approach which moves from the everyday politics of disabled people's lives to the campaigns conducted by the labour movement at regional, national and United Kingdom-wide levels, and on to the pressure exerted by 'miners' MPs' and others in Parliament to secure or influence legislation. It aims, like Watts Morgan, to bring the two together to illustrate how central disabled people were to the broader politics of the coalmining industry. Politics as expressed via the cultural life of the community, particularly the emergent body of coalfields writing in the 1930s, is also touched upon. In this literature, concerns for the body and health of the miner and his family were central to the political sentiments expressed. Crucially, it is important not to treat people with disabilities solely as the objects of all this campaigning activity, but to give attention to their agency and the extent to which they were able to bring their influence to bear on these political and industrial matters.

\section{Industrial relations, coal-mining and disability}

The politics of disability in mining communities and within the industry as a whole occurred within a distinctive context, and some understanding of the 
broader aspects of industrial relations in the coal industry is first necessary. In a British context, the industry was arguably characterised by some of the stormiest and bitterest industrial relations of the late nineteenth and early twentieth centuries. Despite the existence of various mechanisms of collective bargaining, conflict resolution and conciliation, still the industry was marked by a greater propensity to industrial action and strike activity than other areas of the economy. ${ }^{13}$ Moreover, the troubled history of the industry had profound consequences for industrial relations in Britain more generally as the miners' 'triple alliance' with rail and transport workers led to a major dispute in 1921 and as trouble in the coal industry led to Britain's only general strike in $1926 .{ }^{14}$

The period from about 1880 onwards saw huge increases in trade union membership in Britain. The half-million union members in the mid-1870s had increased to four million by 1914, comprising nearly a quarter of the working population, a growth which James Hinton characterised as the formation of 'mass labour movements' and a shift in British working society. ${ }^{15}$ Attempts to unionise coalminers had occurred on a fitful and partial basis through the nineteenth century but, on the whole, unions tended to be weak and short lived, and were rarely coordinated across more than one coalfield. As far as the comparators in this study are concerned, the earlier development of the coalfield in the north-east of England, and the relative maturity of the labour movement, are reflected in the establishment of county unions for Northumberland and Durham, respectively, in the 1860 s and their ability to weather the trade depression of the 1870s more effectively than their counterparts in other coalfields. ${ }^{16}$ More effective trade union organisation did not come to the Scottish coalfields or south Wales until later. Alan Campbell has outlined the 'painstaking, uneven and irregular' growth of trade unions in Scotland before the 1890s, where small, local and fragile miners' associations rose and fell in rapid succession. ${ }^{17}$ More robust county unions were formed in the Scottish coalfields from about the mid-1890s, and trades unionism rapidly grew in strength as larger numbers and proportions of miners joined their respective unions in the last years of the century and the period before the First World War. Greater collaboration across the county unions was brought about by the formation of the Scottish Miners' Federation (later the National Union of Scottish Mineworkers) in $1894 .^{18}$ In south Wales, the small and disparate organisations, often based on individual valleys and acting not as proper trade unions but more as committees to administer the sliding-scale pay mechanism, were only united in a coalfield-wide organisation for the purpose of collective bargaining with the formation of the South Wales Miners' Federation in $1898 .{ }^{19}$ 
More generally, the 1890 s witnessed a significant increase in union membership across the coalfields so that, by the turn of the century, something like two-thirds of all workers in the industry belonged to their respective trade unions and, as John Benson notes, it was from this point that the unions 'were able to exercise a really decisive influence on the life of the individual family. ${ }^{20}$

Trade unionism in the coal industry was given further impetus with the formation of the MFGB, a union of miners' unions, in 1889, and this organisation was to become crucial for the miners' political strategies in relation to disability matters into and during the twentieth century. ${ }^{21}$ With the foundation of this organisation, an attempt was made to unite miners across Great Britain in common cause and to exert pressure on employers in the industry - who were themselves cooperating across their different coalfields to an increasing extent - through the Mining Association of Great Britain, founded in 1854. Differences of opinion meant that it was some time before all coalfield unions were affiliated to the 'national' Federation. Some small Scottish unions affiliated upon the MFGB's inception, while the Scottish Miners' Federation also entered into formal affiliation on its creation in $1894 .^{22}$ The miners of south Wales affiliated to the MFGB later, in 1899, following the abandonment of their commitment to a sliding scale in the previous year, while Durham and Northumberland, opposed to the campaign for an eight-hour day, did not do so until as late as 1907. All district unions were affiliated to the Federation by 1913, by which time it represented the interests of 645,900 miners. ${ }^{23}$

The MFGB was crucial to the politicisation of disability in the twentieth century, since it was the main campaigning body that pursued legislation on disability issues on behalf of miners. Employers' liability and workmen's compensation legislation were matters of real concern to the MFGB right from its inception, as was the campaign for an eight-hour day. Success in the latter, with the passing of an Act of Parliament in 1908, convinced many of the importance of this campaigning, political strategy of the Federation, and subsequent years witnessed attempts to influence safety legislation, medical research, nationalisation of the coal industry and other issues relating to the industry. $^{24}$

Thus, the political landscapes and labour movements of coalfield societies were by no means homogeneous. Unions arose at different times, varied in their strength and the extent of their militancy and entered into different forms of industrial relations with their respective groups of coal employers. Not all miners subscribed to class struggle or even solidarity, and differences according to party political affiliation, religion, ethnicity and nationality served to undermine 
unity, albeit to different degrees, in each coalfield. Added to that, of course, a large a proportion of miners were not members of their respective trade unions and this varied from coalfield to coalfield and in each coalfield over time. Such structural factors, characteristic of the labour movements in each coalfield, were the context in which disabled miners and their families experienced impairment and in which the politics of their disablement was played out.

Miners' trade unions were thus large organisations that were able to wield an increasingly powerful influence on behalf of their members. The organisations that set out to represent miners' wives, and the women of British coalfields more generally, were, in contrast, far smaller and were unable to exert anywhere near the same degree of power. Given the relative paucity of employment for women in coalfield communities, female trade unionism was unimportant and far more activism came through the Labour Party and the Women's Co-operative Guild. Women in the Labour Party were organised in the Women's Labour League, formed in 1906, but this was replaced by 'women's sections' affiliated to local branches with the revision of the Party's constitution in $1918 .^{25}$ As part of this change, the Labour Party also appointed Marion Phillips as its first Chief Woman Officer in 1918, and Elizabeth Andrews performed the same role in Wales from that date; both were tasked with organising Labour women and assisting them in their activities. ${ }^{26}$ Another organisation that campaigned to improve the lives of women in mining communities, in addition to working-class women more generally, was the Women's Co-operative Guild, a women's auxiliary organisation within the Co-operative movement, founded in $1883 .^{27}$

Both these organisations enrolled working-class women in relatively large numbers and looked to utilise their perspectives to help determine the welfare policies they advocated. By 1933, for example, the Labour Party in Wales had 11,207 male members and 9,160 female members (45 per cent of the total) and the south Wales coalfield was a particular stronghold: in 1929 there were ninety-five sections in the East Glamorgan area alone..$^{28}$ As far as the Women's Co-operative Guild is concerned, the historian of the Guild in Wales has identified over 100 branches in existence for at least some time in south Wales during the period between 1891 and $1939,{ }^{29}$ but, there were fewer than 2,000 members in the whole of Wales by $1933 .{ }^{30}$ These various working-class women's organisations shared members in common and cooperated with each other on a regular basis. Such cooperation was also manifest in a more formal alliance from 1919 onwards as the Standing Joint Committee of Industrial Women's Organisations was established. This included representatives of the Labour women's sections and the Women's Co-operative Guild, in addition to female trade unions, and it worked throughout the interwar period and into the 1940s to further welfare 
issues that were intended to improve the lives of working-class women, including housing, maternity and child welfare, and pithead baths. ${ }^{31}$

\section{Disability, advocacy and representation}

Histories of industrial relations have usually focused on the high-level negotiations of the representative leaders of workers and employers that were held to discuss the industry as a whole, or else major sectors of those industries. They have tended to concern themselves with the broader matters that affected the particular trade or industry, and so it has tended to be collective bargaining mechanisms, wage agreements and industrial disputes that have occupied the attention of labour historians. Similarly, the historiography of trade unions has prioritised industrial struggles involving issues such as wages, hours of work and working conditions in rather abstract ways, rather than the meaning of such issues in the personal experiences of individual miners. ${ }^{32}$ In none of this labour history is there much attention given to the material circumstances of life for individual miners and their families, or to the more mundane but crucially important work carried out by branch or lodge officials in defence of the individual worker with a grievance. ${ }^{33}$ Perhaps ironically, considering the commitment to history from below, historians of trade unions have not studied labour politics from the viewpoint of individual union members and have failed to appreciate what trade unions did for, or meant to, individual members on a day-to-day basis. This perspective nevertheless suggests itself as a meaningful way in which to consider the politicised character of disability, since it forces us to consider the experiences and viewpoints of the disabled person.

The vast majority of disabled miners did not see their unions launch large-scale campaigns on their behalf, or at least not on their behalf alone, nor did they find MPs taking their particular cases up in the House of Commons or appealing them in the House of Lords. Rather, the most common experience for disabled miners, if they were indeed members of their respective trade union, was far more mundane: to meet the lodge secretary, to discuss the particular circumstances of their case and for the lodge secretary to seek an adjustment to working conditions or some form of compensation from the manager at the particular colliery. These local, personal relationships with a lodge undersecretary are represented in a novel by Jack Lawson (who would become MP for Chesterle-Street from 1919 to 1949) in Under the Wheels (1934). Jabez Sill, the secretary, is a paternal, even quasi-religious figure (referred to as 'the new prophet') who walks through the community checking on the people and dispensing advice to injured men about compensation and other work disputes. ${ }^{34}$ This lower, micro level was no less political than the higher reaches of the British political 
establishment, however, since it constituted the play of power relations in the most real, intimate and significant level of people's actual lives.

While a perspective that focuses on the individual miner and his impairments is extremely important, miners' trade unions found that, despite each case having unique characteristics, in terms of the circumstances of the individual miner or the manner in which his impairment was caused or affected him, most cases also had a great many features in common. This was because employers, or their insurance companies, tended to take a systematic approach to compensation matters and utilised a set of strategies to limit liabilities across the board. What this meant in practice for trade unions is that while each impaired miner was a case, assisted through personal case work by the union staff, whether at lodge or at 'national' level, such cases also became part of broader union campaigning. For example, any individual miner called for examination by his employer's doctor to judge the severity of his impairment would not have found himself alone but would probably have been joined in the queue at the doctor's surgery by many of his workmates who also suffered impairment. Bert Coombes gives a vivid sense of the scale of routine compensation assessments:

In the room on the left about twenty men are seated on plank forms waiting for the compensation doctors to come and examine them. The signs of injury are plain on most of them, for several have their arms slung, and four are on crutches. It resembles the dressing-station after a battle. Across the passage is another group waiting in a line for the clerk to pay them some compensation. He counts some money out, and calls each man forward to sign for his payment. They will receive not more than thirty shillings, usually less, for a week's compensation, but they are easier in their minds than those in the opposite room, because their claims have been admitted. ${ }^{35}$

Individual cases fed into union industrial strategies whereby broader issues were taken up by union districts or executive committees, or even by the MFGB or miners' MPs in negotiations with employers' representatives. An excellent illustrative example can be found in the case of a miner suffering nystagmus that was taken up by the South Wales Miners' Federation and that reached the House of Lords in 1936. The man had had his claim for compensation dismissed in the county court after returning to work without being certified as being recovered and thereby declaring himself fit to work. This decision was apparently in accordance with a decision taken in the Court of Appeal some years previously and reaffirmed when this particular case was referred to it. The case was considered of such importance that the Trades Union Congress (TUC) appealed the case in the House of Lords, which gave the decision in the miner's favour and established the principle that a return to work did not necessarily mean that 
an injured worker was fully recovered. ${ }^{36}$ It is therefore difficult to draw a clear line between individual case work and the broader industrial strategies of the miners' trade unions. Inevitably, the one informed the other in a very direct fashion, and this is implicit in the discussion that follows.

In the first place, however, not all miners were members of their respective trade unions; at times, quite large proportions of the mining workforce stood outside union membership. To a degree, non-members have been neglected by a labour historiography that has prioritised institutional approaches, for which primary sources have survived and which place union activists and members rather than non-unionists in the foreground. Miners not in union membership have not left many sources to the historian, but they still warrant attention. In the context of disability, non-members might have found their dealings with employers more difficult than their counterparts who benefited from the advocacy available to them by virtue of their union membership. Certainly, trade union officials stressed that employers were more likely to deal favourably with compensation claims from individual miners if they knew the miner was a member of the trade union. There was undoubtedly a rhetorical intent to such assertions, clearly designed to bolster union membership, and no statistical material on the relative success of members and non-members exists to allow us to test the validity of such assertions. But, following union officials' logic, it seems reasonable to assume that employers, intent as they were on limiting liabilities in as many ways as possible, would have resisted claims from non-members quite as vehemently as they did, if not more so, in relation to union members and that the cases of non-union members, who lacked the negotiating skills or were unable to afford the legal representation that union officials could draw upon, could not be carried as far. A somewhat fatalistic assessment, in the case of a miner who fainted from overwork and lost his arm to the conveyor, that 'the Company was always exonerated' is made in Gwyn Jones's Times Like These (1936), reflecting a view that the balance of power was deeply unequal. ${ }^{37}$

Relative to their unionised counterparts, disabled miners not in union membership would have found themselves in a disadvantaged position in their dealings with their employers and would have had to rely on the generosity of the colliery company official with whom they dealt or any personal political capital on which they could draw. ${ }^{38}$ Older miners who had served the particular company for an extended period of time might have been able to draw upon a moral economy - especially during the nineteenth century - that laid a certain level of responsibility for old and infirm miners on the companies in whose service the miner had expended his strength and fitness, while 'good' and 'loyal' workers could be favoured by employers who might have wished to stress values 
such as respectability, thrift and independence or to project a public profile of benevolence and altruism. ${ }^{39}$ This moral economy was eroded by the workings of the workmen's compensation system, as such old and infirm men became a greater liability than other men, but, even by the 1920s, some sort of altruism continued to be shown to impaired workers, albeit in certain, particular circumstances. ${ }^{40}$ In the correspondence between different managers of the Powell Duffryn Coal Company in south Wales, for example, can be seen estimations of the worth of particular individual miners who applied for tickets of admission to a convalescent home - applications from men considered by managers to be a 'decent chap' or 'a regular and fairly good workman' were granted. ${ }^{41}$

Nevertheless, miners who were not members of their trade union found themselves in a relatively powerless relationship. The moral claims that they could call upon or the personal political capital that they could utilise in their dealings with the colliery manager were slight, and very few such miners in this situation would have secured their aims in these instances. Whether they sought light employment or compensation payments, non-union members had few means at their disposal to compel employers to grant their demands. This is not to argue that impaired miners in union membership were in a powerful position, of course, and it is clear that employers were able to bring considerable pressure to bear and to utilise all manner of tactics to lessen their compensation liabilities. ${ }^{42}$ But, as union officials were keen to point out, individual union members were supported in their cases with access to expert medical opinion and good-quality legal representation in order to fight their cases. ${ }^{43}$ In their 'Non-Unionist Campaign' in the early 1930s, for example, the Ferndale and Tylorstown Joint Miners' Lodges in the Rhondda Fach valley drew attention to a case in which a miner had secured a compensation payment of $£ 556$ due to silicosis as a result of the Ferndale Lodge's efforts in a disputed case. It stated that 'To substantiate the claim, a Professor of Geology had to be engaged to certify the rock, chemists to analyse it, medical men to proceed with the usual tests, apart from those engaged with the legal aspect of the case'; 'what ordinary workman could hope to finance a case of this kind, which involves such considerable expense?' it asked. The campaign leaflet also noted that two men had died in an accident at Ferndale previously, one of whom was a member of the union and whose family received $£ 300$ and the other, not a member, whose family were granted $£ 15$. $^{44}$ Similarly, the Durham Miners' Association opined in the 1920s, in light of the harassment they alleged the employers directed at men on compensation, that 'Were it not for the Trade Union the position of the injured would be made helpless and hopeless. ${ }^{45}$

Upon becoming injured, a legal responsibility was placed on the individual miner to report his accident and his injury to the colliery company. He would 
also have reported the injury or complaint to his lodge secretary or, a little later into the twentieth century, the dedicated compensation secretary on the lodge committee. From that point, he would have been represented in negotiations by that union official. Lodge officials took up large numbers of individual cases and this was clearly an important part of their everyday administrative activities as union officers. The Ebbw Vale District of the South Wales Miners' Federation, for example, recorded 247 individual general notices of claims for injury compensation in between July 1900 and March $1901 .{ }^{46}$ Union officials insisted that their organisation was 'more than a trade union', rather a 'social institution' providing an 'all-round service of advice and assistance', with lodge officials who were 'acknowledged social leaders called upon to advise in all kinds of domestic and social problems' 'between the cradle and the grave. ${ }^{47}$ The lodge secretary in the Durham coalfield was referred to as the 'father of his people', and the centrality of the lodge officials to the community was echoed too in the autobiographical writings of miners' leaders. In his memoir, A Man's Life, Jack Lawson wrote: 'If an accident happens, the union looks after the compensation of the unfortunate. And there are men in every northern colliery who can expound the Compensation Law like a lawyer. ${ }^{48}$ Indeed, the individual on the lodge committee, whether the secretary or the compensation official, built up a great deal of experience in compensation matters and was assisted by guides to the legislation prepared by the union for its officials, and briefing sessions on new developments. ${ }^{49}$ In many cases, lodges appointed men as compensation secretaries who had first-hand experience of the compensation system and its intricacies through their own cases; this served the twin purpose, perhaps, of drawing upon the skills and experiences of particular individuals to assist other members while benefiting the individual, ensuring them a role in the union bureaucracy when they were no longer able to work in the industry itself. $^{50}$

The initiation of claims to changed work conditions or compensation payments for disabled miners was replicated across the British coalfields, yet there were subtle but important differences in the ways in which different unions pursued these cases. The coalfield in the north-east of England was developed much earlier than its Scottish and Welsh counterparts and, by the late nineteenth century, possessed a more robust union culture and more stable industrial relations. Writers of the north-east of England coalfield repeatedly express pride in the formation of the union, its strength and the special political character of the north-eastern miner. For example, in Harold Heslop's Last Cage Down (1935) the Darlstone (alias for Durham) miners 'have kept one hundred years of unbroken organization' and are political fighters, unlike the 'new type of miner, the modern, tranquil, mechanized miner, the unorganized and unhistorical miners 
of the Midlands. ${ }^{51}$ Methodism's place in the creation of this enduring political culture and a type of miner who is serious, focused and politically committed is emphasised. $^{52}$

The greater industrial relations stability in the north-east of England was evident in the more consensual politics that surrounded the permanent provident fund movement in the region in the nineteenth century relative to, for example, south Wales, where suspicion and struggle were more characteristic. ${ }^{53}$ Such cooperation was also evident in the new era of workmen's compensation as the 'friendly arrangement' between employers and unions on the Arbitration Committee ensured that fewer cases were contested in the courts. ${ }^{54}$ In Durham a case would be passed on to the Arbitration Committee if the lodge secretary was unable to secure an agreement with the colliery company on the workman's behalf, and would go to court only if agreement could not be reached at that stage. ${ }^{55}$ The result, predictably, was that fewer cases were taken to law: between 1898 and 1922, the Arbitration Committee dealt with over 5,000 cases. ${ }^{56}$ The Durham Miners' Association opined that, even with the increase in contested cases taken to court following the amendment to workmen's compensation legislation in 1923, 'We have yet to be convinced that in the total, our injured would get a greater measure of justice and more compensation from County Court Judges than from the Arbitration Committee. ${ }^{57}$

In south Wales and Scotland, where no such Arbitration Committee existed, the case would be dealt with at colliery level by the lodge official and, in the event of failure to effect an agreement, would then be passed up the union structures, usually to the miners' agent, before reaching the executive committees and subsequently being passed to the MFGB itself for action. These different levels of union structure took cases through the hierarchy of law courts, and legal representation, whether by solicitors or barristers, was secured as appropriate. Lodge officials tended to see cases through the local magistrates' courts, while agents tended to administer cases that had reached the county courts and the MFGB oversaw appeals at the Court of Appeal and the House of Lords. ${ }^{58}$

The advocacy work of lodge compensation secretaries on behalf of individual miners was clearly crucial to the men themselves and to their experience of disability, and this is illustrated most clearly in the constant war of attrition that employers waged on men on partial compensation. Indeed, the constant struggles between 'partial compensation men', also known as 'light employment men', and employers gives a clear insight into the particular power relations between disabled miners and their employers, and demonstrates the considerable disparities in power between the two sides, even when union support was forthcoming. ${ }^{59}$ While problems with the way the Act of 1923 defined incapacity gave rise to a considerable amount of difficulty, at least part of the trouble faced 
by men on partial compensation payments was due to the character of their impairments. ${ }^{60}$ Such men were not sufficiently impaired to be considered incapacitated ('total compensation men') and, instead, tended to have temporary impairments that might change, or indeed lessen, over time, or else permanent conditions where the degree of impairment could lead to disagreement among medical experts. In short, 'partial compensation men' faced impairments where the degree of incapacity was less certain and more open to challenge, interpretation and disagreement.

More generally, the coal industry was a particularly labour-intensive sector of the economy and the costs of labour made up a large proportion of the employers' outgoings. This resulted in constant tension between employers and unions over wages but, in light of the relatively dangerous nature of the coal industry and the comparatively high levels of compensation liabilities, also focused attention on how to reduce the 'burden' of payments to impaired miners. ${ }^{61}$ Coal employers sought and found myriad ways in which to resist or frustrate compensation liabilities and relieve themselves of the financial burdens imposed upon them by the statutory system.

The particular approach to these matters of any coal company varied from place to place and over time. There are instances in which unions observed that the employers were happy to settle cases without recourse to legal action, but these are few and far between and the usual state of affairs was one of conflict and struggle. ${ }^{62}$ At the same time, it is possible to see that there were certain periods in which the number of contested cases or manipulation of the situation by employers was greater. This is especially true of the 1920s, for example, as an amendment to the Workmen's Compensation Act in 1923 included clauses that allowed employers to seek new ways to minimise liabilities. The Durham Miners' Association was exercised by what it perceived as the deliberate harassment of injured miners by the employers through Section 14 of the Act. This gave greater rights to employers to require men in receipt of compensation payments to undergo further medical examinations by the employers' doctors. The subsequent reports invariably found either that the men were recovered or else that the disability had lessened, and the injured miner was given ten days' notice that their payments would lessen or end. To prevent this from happening, the miner was required to submit a counter medical report within those ten days, and this placed enormous pressure on the individual miner and, by extension, his trade union. With over 300 such cases in the last three months of 1925 alone, the Durham Miners' Association believed that the employers deliberately swamped them with more cases than they could manage. ${ }^{63}$ They found that the individual miner, rather than be 'humbugged' by the employer and appear before the employer's doctor, merely restarted work, often before 
he was ready to do so. Either the miner continued work and did not come back onto the compensation lists or, if the miner failed his work subsequently, he found that it was a costly and time-consuming business to restate his case for compensation, without any guarantee that it would be established successfully. The summoning of such miners to repeated medical inspections, asserted the Miners' Association, heaped 'unnecessary humiliation and indignities' on the disabled individual: 'It is provocative', stated the Association, 'and conveys the impression that the injured person is a thief and getting money by false pretences, or that our people took a pride in getting mutilated. ${ }^{64}$ The Rhondda No. 1 District of the South Wales Miners' Federation similarly found that employers in its area were using the clauses of the new Compensation Act to dispute cases and that considerable pressure was placed on union financial resources by the large volume of work created for the union. ${ }^{65}$

Another common tactic utilised by employers to harass light employment men was to cut compensation payments when wage increases were implemented across the industry. This was possible because, for much of the period, the compensation payments of partially disabled miners were calculated with reference to the differences between their pre- and post-injury wages, and miners were awarded half of the difference (it was often referred to in negotiations as 'half difference compensation'). This meant, of course, that impaired miners, unable to earn at the same level as previously, found that their partial compensation payments were insufficient to take them up to their previous income levels, and so disability entailed a fall in living standards for the injured miner and his family. The miners' unions, and indeed the labour movement more generally, campaigned throughout the first half of the twentieth century for compensation payments that were equal to the full wages, but were not successful in this aim, even under the majority Labour government of 1945 that passed significant reforms in social welfare and workmen's compensation legislation. ${ }^{66}$ Employers also took the opportunity to cut compensation payments to individual miners upon the granting of wage awards to miners generally. This was because a wage increase would take an impaired miner's wages closer to, or indeed equal to, the previous level of income and so closed or removed the gap between previous and current wages, with the effect that employers felt justified in cutting the partial compensation accordingly. This happened in response to the 'war bonus' during the First World War, the 'Sankey award' in the immediate post-war years, a wage agreement in 1937 and the 1939 ' war bonus. ${ }^{67}$ Each time, miners' unions were forced to attempt to represent members on partial compensation through negotiation and legal action. ${ }^{68}$

The direct harassment and humiliation of impaired miners was exacerbated by what the disabled men and their trade unions perceived as a more mundane, 
petty unpleasantness that similarly made clear the precise character of the power relations that existed between men on compensation and their employers. For example, the Fife and Kinross Miners' Association lodged an official complaint with the coalowners' association in 1910 in relation to the rudeness and incivility of colliery officials to men who collected their payments at the colliery office each week. ${ }^{69}$ Similarly, in 1917 the Caerau Lodge of the Miners' Federation in south Wales complained to the local coal company at the insensitivity of a representative of the company who had visited an injured man and informed him that he had broken his spine. His condition had been kept from him by his family and doctor, and the 'uncouth' way in which the colliery official had informed him of his condition had plunged him into depression. A report of the incident was passed on to the miners' agent and MP, Vernon Hartshorn, who was to seek to have the official censured. ${ }^{70}$

This particular lodge was required to take up a number of complaints about the rough treatment meted out to disabled members by representatives of the colliery company, particularly in the early 1920s as the company placed pressure on partial compensation men to sign away their rights to compensation in return for permanent jobs on the surface. A series of complaints against the company's doctor, Bentley, culminated in 1924 when the lodge made a stand 'to wipe out these grievances at the Caerau Colliery'. The final straw was a miner with nystagmus who was 'treated like a Dog by Doctor Bentley' in a medical examination. It was reported that 'He told him to stoop down. [The miner] put his hand on the table as he was stooping down. Doctor Bentley knocked his hand off the table and [the miner] asked him if he was just finished. Alright he said you can carry on for a few weeks. ${ }^{71}$ Colliery doctors often had a gruff and robust way about them, and complaints about their bedside manner were not uncommon, but the sense of grievance felt by miner patients and their supporters was that much greater in these cases involving impairment. ${ }^{72}$ These instances also made clear, and indeed were intended to make clear, the particular power relations that disabled miners found themselves in relative to their employers.

While considerable advocacy work was carried out by unions in support of their disabled members, it is important to avoid any overly optimistic or celebratory account of the roles of trade unions. At times, in unfortunate situations and for a variety of reasons, union compensation officials simply failed their members or even refused to offer support. Such failures raise important questions about the power relations that disabled miners entered into with their trade unions, the bodies that were ostensibly intended to defend their interests and bring about an amelioration in their situation. In these instances, the particular power relations between the unions and the disabled miners were not what 
might have been assumed from the rhetoric utilised by trade unions that posited disabled members as an important responsibility for the labour movement and that placed the victims of industrial capitalism at the heart of union campaigning. ${ }^{73}$ This is not to discount the considerable time, effort and resources that miners' unions devoted to the lives and well-being of their disabled members, but only to note that not all disabled miners would have held a favourable view of their respective trade unions.

In the first place, miners in arrears with their union dues were denied assistance in compensation cases; in another instance, a miner from Harthill in Lanarkshire was denied assistance because his injury was sustained while strike breaking during the lockout of $1926 .{ }^{74}$ Union discipline and rules of eligibility needed to be maintained for the sake of industrial strength, and disabled members found themselves in a similar position to other members. At the same time, such rules were not always interpreted strictly: unions often allowed the cases of miners in arrears to progress if they cleared their debts to the union and, in one instance, the chairman of a lodge personally paid off the arrears of one member to allow his case to continue. ${ }^{75}$ Rules were clearly relaxed in order to ensure unity and to offer assistance where it might have been denied.

More frequently, and intriguingly, lodge, district and executive committees were required to deal with complaints from members unhappy that union officials had not taken their cases beyond a certain point, or from miners who were dissatisfied with the quality of the assistance that they had been afforded by the respective union. In some ways, the former type of case was more straightforward and tended to arise through a lack of funds that prevented unions from taking more cases to law than they would have wished. ${ }^{76}$ More frequently, union officials, instructed by their legal counsel, made estimations of the likelihood of success in taking cases to court. As the Fife and Kinross Miners' Association noted:

if we cannot prove the accident, or if the medical evidence is very contradictory and unsatisfactory, then it behoves the Executive to carefully consider whether the case should be pressed, because no matter what our sympathy for the particular man may be, if the law has not provided for the case, or if we cannot legally prove it, then there is little use in pressing it to a litigation. ${ }^{77}$

It is perhaps the second type of case, however, where miners complained about the quality of assistance provided to them, that is most revealing of the power relations that existed between disabled miners and their trade unions, since they rarely resulted in the union admitting fault or making amends for it. $^{78}$ Such cases did not arise particularly often, or at least not as far as trade union minutes record, but it should come as no surprise that the considerable 
pressures and strains, and the importance of the matters at stake, resulted in dissatisfaction and disagreement. Of the small handful of cases that crop up in the records of the South Wales Miners' Federation, it is the case of Rowland Ellis, a 'disabled collier', before the Rhondda No. 1 District that is most instructive. Ellis contrasted the compensation payment of $£ 90$ secured for him by the Federation with the larger payment won for a widow and her children at the same time. Dai Watts Morgan, the Miners' Agent for the District, pointed out that the numbers of children had been taken into account, but also how Ellis had been in receipt of weekly compensation payments in the time before his lump-sum award. More interestingly, Watts Morgan had completely lost patience with Ellis and accused him of ingratitude. Watts Morgan stated: 'I know him. $\mathrm{He}$ is a person whose case we fought for right along from beginning to end, and who then went directly behind the backs of the officials, the solicitor, the District Committee and myself. He thought that we were doing him wrong.' In the event, the meeting passed a resolution that confirmed the District committee's action in the case. ${ }^{79}$ Faced by the considerable power of the trade union, therefore, disabled miners dissatisfied with the quality of representation provided by it had very little recourse to restitution, and union officials possessed considerable authority that was difficult to challenge.

More generally, and apart from the provision or denial of assistance by the trade unions in compensation cases, disabled miners stood in a slightly ambivalent position relative to their trade unions. There were, for instance, a number of factors that lessened the ability of individuals to engage with union activities. Many impaired miners were often disabled from attending trade union meetings or other activities and were not able to make their feelings known. Lewis Jones's novel Cwmardy (1937), for example, describes entire valleys of people attending political meetings 'with the exception of the bedridden' (the effect here is to show how unanimous is the support, but the point is based on recognising incapacity), while Bert Coombes similarly observed that many former miners in the Neath Valley were so debilitated by chest disease that they were unable to leave their homes, except for a trip out of the house in the summer to see the annual chapels procession. ${ }^{80}$ At the same time, however, applications for assistance from impaired miners were a routine matter of business at union lodge meetings, whether the miner was able to attend or not, as friends or family members, or indeed committee members, represented their interests to the meeting. Harold Heslop's novel Last Cage Down includes a scene of a union meeting at the Miners' Hall where, alongside the 'usual trite questions', there were several applications for relief from disabled miners, including 'the weekly applications for trusses and water-beds and loans of the wheel chairs held by the lodge for people suffering from diseases necessitating these things'; the 
minutes of lodge meetings also confirm this picture. ${ }^{81}$ More significant still, perhaps, was the fact that some union lodges offered reduced benefit club membership fees to disabled miners in recognition of their lessened financial status. $^{82}$

A more intriguing aspect of disabled miners' relations with their trade unions is provided by a consideration of industrial disputes, since it is clear that the disabled men on light work and in receipt of partial compensation possessed a different status to their fellow workers. The miners' unions were keen to ensure that employers admitted and observed their liabilities to disabled members, in terms of both compensation payments and the need to provide light employment to them. As such, they insisted that, in the event of the employers giving notice to the workmen of a termination in contracts (i.e. that the miners would be locked out of their work should they fail to accept new working conditions or wage rates offered by the employers), the men on partial compensation payments would retain their right to compensation. In this way, the unions argued that employers could not absolve themselves of their responsibilities to partial compensation men and that they continued to face a responsibility to offer light employment and to pay partial compensation, even in the event of a cessation of work. Lodges in the Rhondda No. 1 District of the South Wales Miners' Federation attempted to make this argument to employers in the District in the lockout in 1921, for example, despite the legal advice they received that they would be unlikely to win any case they took to court on this matter. The legal advice stated while the employers were liable for any loss of income arising from the impairment, it was unlikely that the disabled miner would be able to prove that they were unable to obtain work elsewhere because of their impairment, when it was disruption in the industry, such as happened during an industrial dispute or during a depression in trade, that was responsible for the loss of employment of a large number of men. ${ }^{83}$ Nevertheless, the South Wales Miners' Federation advised all its members just prior to the commencement of the lockout that they should not attempt to go to work, with the exception of the light employment men. ${ }^{84}$ The advice given by the Federation was thus intended to preserve the men's rights to partial compensation because it could not be claimed by the employers that they were not available to work, similar to their non-disabled colleagues, and used by them to deny payments to these men.

In light of the desire for unity in strike actions, and given the treatment meted out to strike breakers, this is a remarkable action on the part of the trade unions. The precious unity that was so sought after was sacrificed, at least to some small degree, by the exemption of partial compensation men on light employment. Breaking a strike was considered the ultimate sin in most mining communities, and yet the union placed the rights of disabled men to 
compensation and light employment above this cardinal rule of industrial unity. This was clearly a principle that was worth defending. Even this commitment to the needs of disabled members could not survive the heightened stakes of the 1926 dispute, however, as the unions called both partial employment men and safety workers - responsible for ensuring that the pits would still be workable after a dispute - out on strike. This was despite the demand from some employers that the partial compensation men should continue to work and was a clear sign of the determination to pursue the dispute to the utmost of the unions' power. ${ }^{85}$ Most employers, however, were particularly hostile during the 1926 lockout. John Swan, the compensation secretary for the Durham Miners' Association, recalled that 'the owners saw to it that no truce existed. War was waged almost on every man in receipt of compensation. ${ }^{86}$ Nevertheless, Barron notes that over 1,000 compensation cases relating to fatal and non-fatal accidents were heard during 1926, possibly out of the desire to 'avoid costly court cases. ${ }^{87}$

Subsequent to the dispute, the South Wales Miners' Federation found that many light employment men were not taken on again by the employers and so was forced to attempt to negotiate their re-employment as best it could. ${ }^{88}$ The Federation also emphasised its belief that employers continued to have a responsibility to find light work for men injured or impaired in their employment, and utilised test cases and negotiations to successfully secure concessions from the employers. One such concession was that the employers agreed to the payment of half the difference between their pre-accident earnings and unemployment benefit to injured miners who had not secured employment. ${ }^{89}$ Here, as in so many other contexts, the miner's trade union acted in the interests of each individual impaired miner and, where they gained any success, made a difference to the living standard and life chances of the miner.

\section{Political strategies and disability}

In the 1937 novel Cwmardy, by the communist Lewis Jones, one of the characters angrily rejects the idea that government ministers or MPs grasp the realities of life for miners:

Who is this Home Secretary ... this man who calls us hooligans and savages? Is he a working man? Have he ever worked down a pit? Have his mother been put in a county court because he have been too bad to work for a week or two? Not on your life! ... They claim they own the pits. All right. Let them come and work the coal themselves if they want it. Let them sweat and pant till their bodies twist in knots as ours have. Let them timber holes whose top they can't see and cut ribs in coal like solid steel..$^{90}$ 
This assertion dramatises the sense of political struggle that is the focus of much of Cwmardy and its sequel, We Live (1939), by drawing parallels between hard work and disability (panting bodies twisted in knots). It gives voice to a widely held view that there was an enormous gulf between the political class and the people they purported to represent. Historical evidence suggests that this was less marked, and certainly that the interests of disabled miners were indeed represented in Parliament. This was because the miners had long pursued an active and relatively successful political strategy that ensured the return of miners' MPs and the pursuit of miners' goals in Parliament. Moreover, the campaigning and lobbying efforts of the miners' unions, the MFGB and the TUC ensured that miners' concerns were registered in high-level debates and discussions of legislation and official policies, even if those representations were too often marginalised or ignored.

Coalminers were one of the most prominent occupational groups to pursue a parliamentary strategy in any meaningful way during the nineteenth century, and succeeded in returning 'miners' MPs' from the 1870 s. ${ }^{91}$ Miners realised early that legislative intervention was a particularly effective means of improving working conditions; more importantly, they were enfranchised in large numbers from the 1870 s onwards, they were sufficiently concentrated in particular constituencies to wield a considerable influence and they were increasingly organised through their trade unions, so that miners became increasingly aware of their electoral power relative to other types of workers and were able to exert their influence during elections. ${ }^{92}$ Thomas Burt and Alexander MacDonald were the first of these miners' MPs - Burt was elected to represent Morpeth, Northumberland in 1874 and served continuously until 1918, while Macdonald represented Stafford from 1874 until his death in $1881 . .^{93}$ Their number was added to in the years that followed so that, by the second half of the 1880s, there was a small but effective group of miners' MPs that succeeded in making the miners' voice heard on safety legislation, employers' liability and other issues. Prominent among these MPs were Thomas Burt, Ben John Wilson, Ben Pickard, William Crawford and William Abraham, as well as others. This early generation of miners' MPs, before 1900, were members of the Liberal Party and were opposed to the socialism that developed in certain parts of Britain, including some coalfields, from the late 1880 s. $^{94}$ The Social Democratic Federation, the International Labour Party and the Labour Party came to challenge the Liberal hegemony from the 1890 s onwards but had not changed it significantly by the time of the outbreak of the First World War. This was despite the fact that the MFGB had established an electoral fund after 1900 to support miner candidates for parliamentary seats and to 
assist those individuals elected to the House of Commons in the miners' interests. $^{95}$

This parliamentary strategy was further strengthened with the MFGB's affiliation to the Labour Party in 1908, at which point all the MPs sponsored by the Federation took the Labour Party whip. ${ }^{96}$ Gradually, the influence of the miners' interest, in the Commons and within the Labour Party, was extended: there were sixteen MPs supported by the MFGB by 1909, though this had fallen to ten by $1914 .^{97}$ By 1924 , however, the MFGB sponsored 40 of the 151 Members returned to Parliament under the Labour Party. ${ }^{98}$ Within the Labour Party, affiliation in 1908 meant that the MFGB was able to return delegates to the annual party conference and, on the basis of its large membership, was able to send a large bloc that was able to wield a not insignificant influence on party policies. ${ }^{99}$ A significant indication of the strength of the miner constituency within the Labour Party was the adoption of nationalisation of the coal industry as an official party policy.

The political strategy of the miners' union movement, through its direct sponsorship of MPs and its influence on Labour Party policy, was further advanced through MFGB's affiliation to the TUC and Scottish unions' relationship with the Scottish Trades Union Congress (STUC). The TUC, especially its Parliamentary Committee, was the political arm of the trade union movement. The Parliamentary Committee was founded in 1872 and was chaired by Alexander MacDonald, the miners' leader. ${ }^{100}$ Its specified aim was to take 'any action that may be necessary to secure the repeal of the penal clauses of the Criminal Law Amendment Act, the Truck Act, the getting of a proper Compensation Act, and to watch over the interests of labour generally in the proceedings of Parliament. ${ }^{101}$ In the years that followed, the TUC pursued aims relating to disability according to a particular way of working: the Parliamentary Committee would decide what steps to take, and then a bill or resolution was drafted and passed to a sympathetic MP, or else deputations were sent to government ministers. Only very occasionally were large demonstration meetings held to build public support for any measure or change. ${ }^{102}$

The role of the Parliamentary Committee was transferred to a new General Council in 1921, which then embarked on a more sustained period of negotiation with government and a more moderate approach to industrial matters, especially under Walter Citrine's period as General Secretary from $1926{ }^{103}$ In addition, the TUC drew on expertise to make its case for improvements to industrial and occupational welfare: Sir Thomas Legge was appointed Medical Officer in 1930 and transformed the TUC's approach to occupational health and welfare issues, including workmen's compensation legislation. ${ }^{104}$ At the 
same time, the economic depression meant that, on the one hand, there was little appetite among resistant employers for statutory interventions and, on the other hand, the labour movement's ability to press for such governmental action was circumscribed. ${ }^{105}$

These various political efforts constituted a technocratic approach to disability, since they largely dealt with the finer points of employers' liability and, more importantly, workmen's compensation, in addition to scientific and medical research into miners' pulmonary disease and nystagmus, with discussions between experts employed or engaged by the TUC and the permanent officials and medical experts of the government. ${ }^{106}$ While industrial strategies were waged by the miners' trade unions to support individual miners or particular groups of disabled men, political efforts were, inevitably, undertaken in a different sphere and with different methods. As Bufton and Melling argue, miners' unions devoted more time and effort to fighting the cases of individual miners rather than 'engaging in a generalized public campaign in favour of comprehensive legislation. ${ }^{107}$ Instead, technical expertise was procured by the miners' movement and utilised in the lobbying of and representation to political leaders and government experts. $^{108}$

This is most clear in the numerous activities relating to legislation - resolutions on the system of workmen's compensation might have been passed by miners' meetings, in all coalfields and on a regular basis, but such resolutions fed into MFGB, TUC, STUC and Labour Party efforts in Westminster, whether this be through the introduction of legislation or through efforts to shape legislation as it was being passed by other political parties. Huge amounts of effort and resources went into attempts to influence or amend the Employers' Liability Act of 1880 and the workmen's compensation legislation passed in 1897 and amended in the decades that followed. Apart from the behind-the-scenes lobbying and representation that took place, pressure was also exerted through the rhetoric employed by MPs in the numerous parliamentary debates that took place on these matters, and miners' MPs found themselves in battle with Members who were allied to the coal employers to a greater or lesser degree. ${ }^{109}$ In a debate on accidents in mines just after a colliery disaster in Scotland in 1925, for example, Robert Smillie, the Scottish miners' leader and MP for Morpeth, engaged in some typical labourist rhetoric as he lambasted the apathy that tended to follow in the wake of major losses of life in the coal industry:

we have got so used to slaughter during the War that we are not so easily shocked now. If you take a period of 70 or 90 years in the history of Great Britain prior to the War, you would find that a larger number were killed and injured in the mines than were killed and injured in all our battles during that time. The slaughter has gone on all the time. ${ }^{110}$ 
Following the passage of the Workmen's Compensation Act in 1897, miners' unions campaigned vigorously for different diseases to be included in the list of conditions covered by the statutory system. This is most evident in relation to efforts from the 1920s onwards to have miners' chest complaints scheduled as an industrial disease under the statutory system. ${ }^{111}$ The South Wales Miners' Federation, in particular, has been recognised for engaging in what Michael Bloor describes as 'more than 10 years of political lobbying, legal arguments and epidemiological data gathering' before the compensation amendment of 1943, while McIvor and Johnston have similarly emphasised the crucial role played by the MFGB and the miners' trade union movement more generally. ${ }^{112}$ These years were the nadir of the pneumoconiosis crisis, with over 22,000 miners out of work from the disease, 85 per cent of whom were in south Wales. ${ }^{113}$ During this time, the MFGB campaigned consistently at local, national and parliamentary level to raise awareness of the effect of the disease. No annual conference of the MFGB passed without resolutions on the workmen's compensation system and, from the 1920s onwards, chest disease being passed; the conference of 1927, for example, maintained that 'miners phthisis, rheumatism, or any other disease which can be proved to have been wholly or partially due to the nature of employment, shall be included in the schedule of diseases." ${ }^{\text {"114 }}$

While the political campaigns of miners focused on Parliament, those of the women of mining communities were directed more to local government. The organisations that campaigned on behalf of women in mining communities undertook a number of campaigns and initiatives in the period before the First World War - the Women's Co-operative Guild and the Women's Labour League were most prominent in that period - but it is the interwar period that witnessed a significant increase in female activism and influence. Labour women were perhaps the most important groups in the coalfields and, while not able to exert much influence on the direction of party policy on a national level, they succeeded, through local Labour parties, in gaining election to Boards of Guardians and local councils where they were far more able to bring their expertise to bear and make a material difference to the provision of welfare. ${ }^{115}$ Women's Cooperative Guild members also sought and gained elected positions on Boards of Guardians, district and county councils, and found their way onto education, health and maternity and child welfare committees. Rose Davies, a prominent Labour activist and member of the Women's Co-operative Guild, and elected as a district and later county councillor in Aberdare from 1925, for example, was the major driving force behind her council's maternity centre. ${ }^{116}$

Even where female activists in the coalfields were not able to gain seats on local councils, they still canvassed local councillors and exerted pressure upon 
them to improve welfare services for working-class women. The area of provision that received most attention was maternity and child welfare. Feminist campaigners were keen to demonstrate the relative risks faced by women and their husbands and often made the point that miners' wives faced even greater risks to their health and well-being than did their husbands in the notoriously dangerous coal industry. Elizabeth Andrews opined that 'The miner's wife in those days ran greater risks at childbirth than her man in the pit." ${ }^{117}$ Eleanor Rathbone, perhaps the most prominent feminist of the 1920s, estimated that 'A miner's wife runs from three to six times as much danger of death when she has a child as her husband does in going down the pit daily for a year. ${ }^{, 18}$

Such feminists were given the opportunity to exert some pressure and bring about improvements by the Maternity and Child Welfare Act of 1918, which stipulated that local councils were to ensure that county council Maternity and Child Welfare committees were to have at least two female members. The Act required them to co-opt female representatives from women's organisations if no female councillors were available. Labour women were keen to remind councils of their obligations in this regard. ${ }^{119}$ In the Rhondda valley the local members of the Women's Co-operative Guild utilised their presence on the local Mid-Rhondda Trades and Labour Council (TLC), an organisation that brought various organisations within the labour movement together, to compel district councillors associated with the TLC to use their influence on the council to co-opt working-class women who were members of the local labour movement. ${ }^{120}$ Maternity and child welfare was also extremely important on Clydeside and in the surrounding coalfield districts, where motherhood was characterised by female activists as 'the most dangerous of trades.' ${ }^{121}$

Campaigns to develop maternity services intended to improve maternal health and prevent the great toll in reproductive impairment that impacted on mining women. Another important campaign that was partly intended to do the same thing was that in support of the extension of pithead baths to greater numbers of collieries. Branches of the Women's Labour League in south Wales took up the matter of pithead baths from 1912 and a coalfield-wide campaign ensued in the years that followed. This campaign received support from the miners' union, and also from middle-class reformers in the region and, indeed, coal companies such as the Ocean Coal Company. ${ }^{122}$ Elizabeth Andrews, the Wales Women's Organiser for the Labour Party, placed the matter of pithead baths at the centre of her testimony to the Sankey Commission into the coal industry in 1919 and thereby succeeded in getting it placed on the political agenda for the rest of the interwar period; the MFGB and the Labour Party itself gave the issue a great deal of prominence and helped to move the movement forward. ${ }^{123}$ Miners' leaders Robert Smillie and Frank Hodges noted that without 
the introduction of pithead baths, miners' wives and mothers would remain 'life-long slaves of the pit.'

Crucially, the report of the Sankey Commission led the government to establish the Miners' Welfare Fund, which took the matter up from 1927 onwards and made grants towards the erection of baths in coalfields across Britain: a few baths were opened in the immediate post-war years and 1920s, but the pace of expansion increased considerably in the 1930s and 1940s; 307 had been erected by the outbreak of the Second World War and this had increased to 348 by the end of the war. ${ }^{125}$ When the coal industry was nationalised in 1947, the NCB undertook to ensure that every new pit would be equipped with a baths, and looked to provide all pits still without a baths by that time within seven years. ${ }^{126}$ With the extension of such facilities to a greater number of pits, women's campaigning in the coalfields helped to make a material difference to the working lives of women in mining communities and helped to lessen the risks of reproductive impairment. In a sense, perhaps, the campaigns to improve women's reproductive health and lessen the impairment that resulted from childbirth were more successful than the efforts of miners' trade unions to shape the statutory compensation legislation for their members. This was because maternalist politics coincided with official concerns about the size and fitness of the British population and the importance attached to industrial productivity and military preparedness in the defence of Britain and its empire against foreign competitors from the late nineteenth century onwards.

\section{Conclusion}

Disability is inherently political. The denial of rights, opportunities and experiences to disabled people and the resultant experience of disability makes this inevitable. This was evident in a number of different contexts in relation to the British coal industry, from the level of personal experience to the highest political stage of the land. As far as the latter is concerned, it is possible to discern a process of politicisation, largely brought about by statutory interventions and official policies, that witnessed disability issues become the matter of party manifestos, parliamentary debates and significant enactments of legislation. Indeed, it might be argued that such politicisation reached its apogee in the 1930s and, especially, 1940s as official attention was increasingly drawn to disability in the coalfields, as scientific and medical research, supported by government, was conducted and as measures such as the Disabled Persons (Employment) Act of 1944 and the National Insurance (Industrial Injuries) Act of 1946, for all their flaws, were passed. 
More interestingly, disability was political at the personal, individual level, as disabled miners found themselves enmeshed in unequal power relations with individuals and agencies around them. This was most marked in relation to the coal employers but was not wholly absent from their dealings with their own unions, the bodies that proclaimed to fight their cause. Due to the character of the primary source material that has come down to us, this is a very difficult issue to examine, but historians would be well served by asking what kinds of power were communicated in disability issues and, more importantly, how much of that power was negotiated by disabled people themselves. Disabled people have been largely ignored in the historiography of coal, despite unions' continuous campaigning for their rights and compensation, and the perspectives of disabled miners have rarely figured in accounts of the history of the industry. ${ }^{127}$ Nevertheless, while disabled miners occasionally found themselves dissatisfied with their unions, very few seemed to be in any doubt that it was their work that had impaired them and their employers who disabled them through the denial of a just compensation settlement. There is little evidence of any disability consciousness having developed in the coalfields and, instead, miners and their families tended to view disability through the lens of class consciousness. Disability and class consciousness intersect most obviously in coalfields literature, particularly in portrayals of solidarity which use the rhetoric and imagery of disability to achieve their impact. This and other characteristics and traditions of coalfields literature are discussed in our final chapter.

\section{Notes}

1 Hansard, 3 May 1922.

2 On the politics of disability, see Michael Oliver, The Politics of Disablement (Basingstoke: Macmillan, 1990); David Mitchell and Sharon Snyder, The Biopolitics of Disability: Neoliberalism, Ablenationalism, and Peripheral Embodiment (Ann Arbor: University of Michigan Press, 2015).

3 For key works in the comparative coalfield societies literature, see Stefan Berger, Andy Croll and Norman LaPorte (eds), Towards a Comparative History of Coalfield Societies (Aldershot: Ashgate, 2005); John McIlroy, Alan Campbell and Keith Gildart (eds), Industrial Politics and the 1926 Mining Lockout: The Struggle for Dignity (Cardiff: University of Wales Press, 2004); Stefan Berger, 'Working-Class Culture and the Labour Movement in the South Wales and Ruhr Coalfields, 1850-2000: A Comparison', Llafur, 8:2 (2001), pp. 5-40; David Gilbert, Class, Community, and Collective Action: Social change in two British coalfields, 1850-1926 (Oxford: Clarendon Press, 1992); Roger Fagge, Power, Culture and Conflict in the Coalfields: West Virginia and South Wales, 1900-1922 (Manchester: Manchester University Press, 1996); Leighton S. James, The Politics of Identity and Civil Society in Britain 
and Germany: Miners in the Ruhr and South Wales 1890-1926 (Manchester: Manchester University Press, 2008).

4 Scottish Labour Party MP 1922-31 (Coatbridge) and 1935-45 (Bothwell).

5 Labour Party MP 1918-22 (Barnard Castle).

6 Labour Party MP 1919-49 (Chester-le-Street).

7 In 1918 Keating unsuccessfully bid for the Labour parliamentary candidacy; in 1923 he was elected a Labour councillor in Mountain Ash.

8 Contested as Labour Party candidate on South Shields Council 1926, sponsored by the Miners' Lodge. He won a seat on the Taunton Town Council for Labour in 1948, and unsuccessfully stood as the Labour Party candidate for North Devon in 1955 .

9 Having previously been both a member of the Communist Party and the Labour Party, he stood as the candidate for the Liberal Party in Neath in 1928.

10 Jack Jones was a CP member 1920-23, chosen as Corresponding Secretary for the South Wales Region, founding a branch at Merthyr Tydfil; Lewis Jones was Welsh organiser for the NUWM, and elected as a CP member of the Glamorgan County Council in 1936.

11 Harold Heslop represented Harton colliery on the council of the Durham Miners' Association; John Swan was elected Agent for the Association in 1923, and later became its General Secretary 1935-45.

12 This is discussed in detail in the second half of Chapter 6.

13 Roy Church and Quentin Outram, Strikes and Solidarity: Coalfield Conflict in Britain (Cambridge: Cambridge University Press, 2002).

14 Barry Supple, The History of the British Coal Industry: Volume 4. 1913-1946: The Political Economy of Decline (Oxford: Clarendon, 1987); Alan Campbell, Nina Fishman, David Howell (eds), Miners, Unions, and Politics, 1910-47 (Aldershot: Scolar Press, 1996).

15 James Hinton, Labour and Socialism: A History of the British Labour Movement, 1867-1974 (Brighton: Harvester Press, 1983), p. 24.

16 John Benson, British Coalminers in the Nineteenth Century: A Social History (Dublin: Gill and Macmillan, 1980), pp. 198-9.

17 Alan Campbell, The Scottish Miners, 1874-1939. Volume Two: Trade Unions and Politics (Aldershot: Ashgate, 2000), p. 117.

18 Campbell, The Scottish Miners, 1874-1939. Volume Two, pp. 15-71.

19 V. L. Allen, The Militancy of British Miners (Shipley: Moor Press, 1981), p. 22; Hywel Francis and David Smith, The Fed: A History of the South Wales Miners in the Twentieth Century (London: Lawrence and Wishart, 1980), pp. 1-2. The 'sliding scale' was the mechanism utilised in some coalfields by which wages paid to workers rose or fell in direct relation to changes in the price of coal.

20 Benson, British Coalminers in the Nineteenth Century, p. 199.

21 On the MFGB, see Keith Gildart, 'The Miners' Federation of Great Britain', in Gildart (ed.), Coal in Victorian Britain, Part II: Coal in Victorian Society, Volume 6, Industrial Relations and Trade Unionism (London: Pickering \& Chatto, 2012), 
pp. 183-92; R. Page Arnot, The Miners: A History of the Miners' Federation of Great Britain (London: George Allen \& Unwin Ltd, 1949), pp. 90-116; Hinton, Labour and Socialism, pp. 45-6; H. A. Clegg, Alan Fox and A. F. Thomson, A History of British Trade Unions since 1889, Volume 1: 1889-1910 (Oxford: Clarendon Press, 1964), pp. 98-111.

22 Campbell, The Scottish Miners, 1874-1939. Volume Two, p. 41.

23 Gildart 'The Miners' Federation of Great Britain', pp. 183-4.

24 Arnot, The Miners, pp. 90-116; David Howell, “All or Nowt”: The Politics of the MFGB', in Alan Campbell, Nina Fishman and David Howell (eds), Miners, Unions and Politics, 1910-47 (Aldershot: Scolar Press, 1996), p. 43.

25 Martin Francis, 'Labour and Gender', in Duncan Tanner, Pat Thane and Nick Tiratsoo (eds), Labour's First Century (Cambridge: Cambridge University Press, 2000), p. 192.

26 Brian Harrison, 'Phillips, Marion (1881-1932)', Oxford Dictionary of National Biography (23 September 2010),www.oxforddnb.com/view/10.1093/ref:odnb/ 9780198614128.001.0001/odnb-9780198614128-e-37852 (accessed 28 August 2018); Ursula Masson and Lowri Newman, 'Andrews, Elizabeth (1882-1960)', in Keith Gildart and David Howell (eds), Dictionary of Labour Biography. Volume XII (Basingstoke: Macmillan, 2004), pp. 1-11.

27 Gillian Scott, Feminism and the Politics of Working Women: The Women's Co-operative Guild, 1880s to the Second World War (London: UCL Press, 1998).

28 Evans and Jones, “'To Help Forward the Great Work of Humanity”', pp. 220-2.

29 Helen Thomas, “'Democracy of Working Women”: The Women's Co-operative Guild in South Wales, 1891-1939', Llafur, 11:1 (2012), p. 153.

30 Thomas, 'Democracy of Working Women', p. 154.

31 Elizabeth Andrews, A Woman's Work is Never Done (Ystrad Rhondda: Cymric Democrat Publishing Society, 1956), pp. 28-31.

32 Keith Gildart, 'Introduction', in Gildart (ed.), Coal in Victorian Britain. Part II, Coal in Victorian Society. Volume 6, Industrial Relations and Trade Unionism (London: Pickering \& Chatto 2012), pp. xiii-xvi.

33 A point also made by John Benson; Benson, British Coalminers in the Nineteenth Century, pp. 206-7. There are some small exceptions to this trend; see, for example, Mark E. Bufton and Joseph Melling, "AA Mere Matter of Rock": Organized Labour, Scientific Evidence and British Government Schemes for Compensation of Silicosis and Pneumoconiosis among Coalminers, 1926-1940', Medical History, 49:2 (2005), p. 167 and George R. Boyer, 'What Did Unions Do in Nineteenth-Century Britain?', Journal of Economic History, 48:2 (1988), pp. 319-32.

34 Jack Lawson, Under the Wheels (London: Hodder \& Stoughton, 1934), p. 77.

35 B. L. Coombes, These Poor Hands: The Autobiography of a Miner working in South Wales, with an Introduction by Bill Jones and Chris Williams (Cardiff: University of Wales Press, 2002 [1939]), p. 160.

36 South Wales Miners' Federation, Annual Report of Executive Council, 1936-1937, p. 44. 
37 Gwyn Jones, Times Like These (London: Victor Gollancz, 1979), p. 287.

38 Bartrip also speculates that non-unionised workers were at a disadvantage relative to their unionsed colleagues; P. W. J. Bartrip, Workmen's Compensation in Twentieth Century Britain (Aldershot: Avebury, 1987), p. 23.

39 On the moral economy of aged and infirm miners, see Ben Curtis and Steven Thompson, “"This is the Country of Premature Old Men”: Ageing and Aged Miners in the South Wales Coalfield, c.1880-1947, Cultural and Social History, 12:4 (2015), p. 597; for an example of this moral economy in a Scottish context in the middle decades of the twentieth century, see Scottish Oral History Centre Archive, Coal Mining Oral History Project, John Taylor Murphy interviewed by Ian MacDougall, 16 May 1997, comments on the Fife Coal Company. On employer paternalism in the coal industry, see Roy A. Church, The History of the British Coal Industry, Volume 3: 1830-1913: Victorian Pre-Eminence (Oxford: Clarendon Press), pp. 274-99.

40 On the unintended consequences of compensation legislation and its role in the lessening of exmployment changes for impaired workers, see Sarah F. Rose, No Right to be Idle: The Invention of Disability, 1840s-1930s (Chapel Hill: University of North Carolina Press, 2017).

41 Glamorgan Archives, Powell Duffryn Collection, DPD/2/5/6/206, Applications for tickets for Porthcawl Rest, May-Sept. 1926.

42 D. C. Davies, compensation secretary at Ffaldau Lodge of the Miners' Federation in south Wales was adamant that the entire compensation system before 1948 was weighted very much in the employers' favour; South Wales Miners' Library, Swansea University (hereafter SWML), AUD/382, D.C. Davies oral history interview, 19 June 1976.

43 Instructive here is Michael Bloor, 'The South Wales Miners Federation, Miners' Lung and the Instrumental Use of Expertise, 1900-1950', Social Studies of Science, 30:1 (2000), pp. 125-40.

44 South Wales Coalfield Collection, Swansea University (hereafter SWCC), MNA/ NUM/L/33/45, Ferndale and Tylorstown Joint Miners' Lodges, Non-Unionist Campaign (Ferndale, c.1932).

45 Durham County Record Office (hereafter DCRO), D/DMA Acc 1004 D 169, Durham Miners' Association, Review of the Work of the Compensation Department for the year 1925, p. 488.

46 Gwent Archives, D.844.20-72, Ebbw Vale and District Miners' Federation, General notices re. injuries and claims, 1898-1914.

47 Will Paynter, My Generation (London: Allen and Unwin, 1972), pp. 110-11.

48 K. Brown, 'The Lodges of the Durham Miners' Association, 1869-1926', Northern History, 23 (1987), p. 146. Jack Lawson, A Man's Life (London: Hodder \& Stoughton, 1944), p. 137. For more on mining autobiography, see Keith Gildart, 'Mining Memories: Reading Coalfield Autobiographies', Labor History, 50:2 (2009), pp. 139-61.

49 See, for example, The Fabian Society, The Workmen's Compensation Act What It Means, and How to Make Use of It (London: Fabian Society, 1900); Harold J. 
Finch, South Wales Miners' Federation, Guide to Workmen's Compensation Act, 1925-43 (Cardiff: South Wales Miners' Federation, 1944).

50 For examples of miners who became compensation secretaries after gaining experience in their own cases, see SWML, AUD/56, Haydn Mainwaring oral history interview (1980); SWML, AUD/222, Dick Cook interview (1974).

51 Harold Heslop, Last Cage Down (London: Lawrence Wishart Books, 1984), p. 139.

52 For a history of Methodism in the Durham coalfields, see Robert Moore, Pit-men, Preachers and Politics: The Effects of Methodism in a Durham Mining Community (Cambridge: Cambridge University Press, 1974.).

53 Steven Thompson, 'Varieties of Voluntarism in the South Wales Coalfield, circa 1880-1948', in Colin Rochester, George Campbell Gosling, Alison Penn and Meta Zimmeck (eds), Understanding the Roots of Voluntary Action: Historical Perspectives on Current Social Policy (Brighton: Sussex Academic Press, 2011), pp. 82-94.

54 On 'friendly arrangements', see North East England Mining Archive and Research Centre, University of Sunderland, NUMDA/6/1/1/1, Durham Miners' Association, Reports of the Compensation Department, Volume I, Arbitration Committee, Report of Proceedings of Arbitration Committee Meeting held in The Coal Trade Offices, Newcastle-on-Tyne on 3 March 1919; Bartrip notes that the Arbitration Committee in the Durham coalfield was one of the few such bodies established in any industry during the first half of the twentieth century; Bartrip, Workmen's Compensation in Twentieth Century Britain, p. 19.

55 On the consensus between employers and unions, see John Benson, 'Coalminers, Coalowners and Collaboration: The Miners' Permanent Relief Fund Movement in England, 1860-1895', Labour History Review, 68:2 (2003), pp. 181-94; on the different politics in south Wales, see Thompson, 'Varieties of Voluntarism in the South Wales Coalfield. On Durham, see Brown, 'The Lodges of the Durham Miners' Association', p. 143.

56 DCRO, D/DMA Acc 1004 D 169, Durham Miners' Association, Review of the Work of the Compensation Department for the year 1922, p. 355.

57 Durham Miners' Association, Review of the Work of the Compensation Department during the year 1924, p. 871.

58 Bartrip, Workmen's Compensation in Twentieth Century Britain, pp. 22-7, 59-63, 133-6.

59 In addition, this class of 'partial compensation' men, for whom 'light employment' was necessary, ensured that the tendency for workmen's compensation legislation to discourage employers from appointing impaired miners or retaining them in employment was not total; on this matter in a different context, see Sarah F. Rose, No Right to be Idle: The Invention of Disability, 1840s-1930s (Chapel Hill: University of North Carolina Press, 2017).

60 Bartrip, Workmen's Compensation in Twentieth Century Britain, pp. 153-7.

61 For examples of union recognition of this situation, see SWML, South Wales Miners' Federation, Annual Report of Executive Council, 1935-1936, p. 31; DCRO, 
D/DMA 91, Durham Miners Association, Review of the Work of the Compensation Department for the year 1924, p. 869.

62 For an example of coalowners preferring not to take cases to law, see SWCC, Swansea University, MNA/NUM/3/8/10a, South Wales Miners' Federation Rhondda No. 1 District, Monthly Report, 14 October 1901.

63 DCRO, D/DMA Acc 1004 D 169, Durham Miners' Association, Review of the Work of the Compensation Department for the year 1925, pp. 488-9.

64 DCRO, D/DMA Acc 1004 D 169, Durham Miners' Association, Review of the Work of the Compensation Department for the year 1925, p. 489.

65 The Colliery Workers' Magazine, 1:4 (April 1923), p. 94.

66 Rodney Lowe, The Welfare State in Britain since 1945 (London: Macmillan, 1993).

67 For examples, see SWMF Executive Council Minutes, 22 May 1915, 8 June 1915, 10 August 1915, 4 June 1920, 2 August 1924, 24 September 1924, 27 September 1924; SWMF Annual Report of Executive Council, 1940-1941, Report of Compensation Department, p. 45.

68 SWMF Executive Council Minutes, 12 February 1916.

69 National Library of Scotland (hereafter NLS), Dep 304/3, Fife and Kinross Miners' Association, Board Meeting Minutes 24 February 1910.

70 SWCC, MNA/NUM/L/19/4, Caerau Lodge, Committee Meeting Minutes, 8 February 1917.

71 SWCC, Swansea University, MNA/NUM/L/19/4, Caerau Lodge, Committee Meeting Minutes, 13 March 1924.

72 On doctor-patient relations in one coalfield, see Steven Thompson, 'Paying the Piper and Calling the Tune? Complaints against Doctors in Workers' Medical Schemes in the South Wales Coalfield', in Jonathan Reinarz and Rebecca Wynter (eds), Complaints, Controversies and Grievances in Medicine: Historical and Social Science Perspectives (London: Taylor \& Francis, 2015), pp. 93-108.

73 A good example can be found in SWCC, South Wales Miners' Federation, Rhondda No. 1 District, Monthly Report, 6 May 1918.

74 NLS, Acc 4312/2, National Union of Mineworkers, Minute Book, 1920-1927, 8 January 1927.

75 For examples, see SWCC, MNA/NUM/L/19/3, Caerau Lodge, Committee Meeting Minutes, 2 November 1912; SWCC, 29 November 1912; SWCC, MNA/ NUM/L/19/7, Committee meeting minutes, 6 July 1922; SWCC, 28 February 1924.

76 For example, see SWCC, MNA/NUM/3/8/10a, South Wales Miners' Federation Rhondda No. 1 District, Annual Report for 1913, p. 2.

77 NLS, Dep 304/3, Fife and Kinross Miners' Association, Executive Committee Meeting, 23 January 1912; for examples of this in practice, see NLS, Edinburgh, Acc. 4312/12, Mid and East Lothian Miners Association, Executive Committee Minutes, 22 June 1927; ibid., 22 August 1928.

78 For an indicative example of a union confirming the decisions and actions of its officials after a complaint from a member, see SWCC, MNA/NUM/3/1/1, South 
Wales Miners' Federation, Executive Council Minutes, 3 February, 10 February, 8 May 1913.

79 SWCC, MNA/NUM/3/8/10a, South Wales Miners' Federation Rhondda No. 1 District, Monthly Report, 4 January 1904.

80 Lewis Jones, Cwmardy and We Live (Cardigan: Parthian, 2006), p. 207; B. L. Coombes, Miners Day (Harmondsworth: Penguin Books, 1945), p. 113.

81 Heslop, Last Cage Down, p. 96.

82 SWCC, Swansea University, SWCC/MNA/NUM/3/8/7(d), Maesteg District, Benefit Fund Rules, 1934.

83 Rhondda No. 1 District, Monthly report, 4 April 1921: Committee Minutes, 7, 21 March 1921.

84 SWMF Executive Council Minutes, 26 February 1912.

85 SWMF Executive Council Minutes, 3 May 1926.

86 John Swan, cited in Hester Barron, The 1926 Miners' Lockout: Meanings of Community in the Durham Coalfield (Oxford: Oxford University Press), p. 122.

87 Barron, The 1926 Miners' Lockout, p. 122.

88 South Wales Miners' Federation, Council Meeting, 22 January 1927; Council Meeting, 21 February 1927.

89 South Wales Miners' Federation, Council Meeting, 31 December 1926, 18 January 1927.

90 Jones, Cwmardy and We Live, p. 268. See Chapter 6 for an extended discussion.

91 On the parliamentary strategies of miners' unions, see Clegg, Fox and Thomson, A History of British Trade Unions since 1889, pp. 239-49, 269-304, 364-422; Keith Gildart, 'Labour Politics', in Gildart, Coal in Victorian Britain, Part II: Coal in Victorian Society, Volume 6, pp. 385-94.

92 Clegg, Fox, and Thomson, A History of British Trade Unions since 1889, p. 271.

93 Clegg, Fox, and Thomson, A History of British Trade Unions since 1889, p. 51.

94 Gildart, 'Labour Politics', p. 385; Clegg, Fox and Thomson, A History of British Trade Unions since 1889, p. 273.

95 Gildart, 'Labour Politics', p. 388.

96 Gildart, 'Labour Politics', p. 388.

97 Gildart, 'Labour Politics', p. 390.

98 Howell, “'All or Nowt”: The Politics of the MFGB', p. 40.

99 Howell, “'All or Nowt”: The Politics of the MFGB', p. 39.

100 The Scottish TUC's Parliamentary Committee was also chaired by a miners' representative, Robert Smillie, for a time; see Angela Tuckett, The Scottish Trades Union Congress: The First 80 Years (Edinburgh: Mainstream Publishing, 1986), p. 42.

101 Ross M. Martin, TUC: The Growth of a Pressure Group 1868-1976 (Oxford: Clarendon Press, 1980), p. 43; see also Clegg, Fox and Thomson, A History of British Trade Unions since 1889, p. 250.

102 Clegg, Fox and Thomson, A History of British Trade Unions since 1889, pp. 252-3. 
103 Vicky Long, The Rise and Fall of the Healthy Factory: The Politics of Industrial Health in Britain, 1914-60 (Basingstoke: Palgrave Macmillan, 2011), pp. 89-91.

104 Long, The Rise and Fall of the Healthy Factory, pp. 91, 96-7.

105 Long, The Rise and Fall of the Healthy Factory, p. 122.

106 Long, The Rise and Fall of the Healthy Factory, pp. 95-6.

107 Bufton and Melling, "'A Mere Matter of Rock”, p. 167.

108 Long, The Rise and Fall of the Healthy Factory, pp. 95-6; Bloor, 'The South Wales Miners Federation, Miners' Lung and the Instrumental Use of Expertise'.

109 On the coal employers and their parliamentary strategies, see Quentin Outram, 'Class Warriors: The Coalowners', in McIlroy, Campbell and Gildart, Industrial Politics and the 1926 Mining Lockout; Ronald Johnston, Clydeside Capital, 1870-1920: A Social History of Employers (East Linton: Tuckwell, 2000), esp. pp. 125-6.

110 House of Commons Debates, 31 March 1925 vol. 182 cc1245-1246.

111 This is one of the most important areas of miners' unions' campaigning on occupational health; see, for example, Paul Weindling, 'Linking Self Help and Medical Science: The History of Occupational Health', in Paul Weindling (ed.), The Social History of Occupational Health (London: Croom Helm, 1985), p. 17.

112 Michael Bloor, 'No Longer Dying for a Living: Collective Responses to Injury Risks in South Wales Mining Communities, 1900-47', Sociology, 36 (2002), p. 100. For more on the campaigning of miners' unions, see Arthur J. McIvor and Robert Johnston, Miners' Lung: A History of Dust Disease in British Coal Mining (Aldershot: Ashgate, 2007), pp. 74, 185-200.

113 Francis and Smith, The Fed, p. 439.

114 SWCC, MNANUM/3/1/1, Minutes of the SWMF Annual Conference, 1-2 July 1927.

115 Francis, 'Labour and Gender', pp. 196-7.

116 Lowri Newman, "'Providing an opportunity to exercise their energies": The role of Labour Women's Sections in Shaping Political Identities, South Wales, 1918-1939', in Ester Breitenbach and Pat Thane (eds), Women and Citizenship in Britain and Ireland in the Twentieth Century: What Difference did the Vote Make? (London: Continuum, 2010), p. 35.

117 Elizabeth Andrews, A Woman's Work is Never Done, edited by Ursula Masson (Dinas Powys: Honno, 2006 [1957]), p. 41. More generally, see Jones, 'Counting the Cost Of Coal'.

118 At the same conference at which Rathbone made this statement, Dr J. H. Jenkins, Medical Officer of Health for the Rhondda valleys in south Wales stated his opinion that childbirth was appromiately four times more dangerous than working underground in the coal industry; Western Mail, 13 January 1926, pp. 7, 10.

119 Newman, '"Providing an opportunity to exercise their energies"', p. 35.

120 National Library of Wales, MS18148E, Minute book of Mid-Rhondda Trades and Labour Council, 1 February 1918; 7 February 1918. For further evidence of the 
importance of maternity and child welfare in Labour women's campaigns, see National Library of Wales, Labour Party Archives, Minutes of the East Glamorgan Women's (Labour) Advisory Council, 1933-44, passim.

121 Annmarie Hughes, “"The Politics of the Kitchen” and the Dissenting Domestics: The ILP, Labour Women and the Female "Citizens" of Inter-War Clydeside', Scottish Labour History, 34 (1999), p. 46.

122 Neil Evans and Dot Jones, “'A Blessing for the Miner's Wife”: The Campaign for Pithead Baths in the South Wales Coalfield, 1908-1950', Llafur, 6:3 (1994), pp. 14-15.

123 Neil Evans and Dot Jones, “"To Help Forward the Great Work of Humanity”: Women in the Labour Party in Wales', in Duncan Tanner, Chris Williams and Deian Hopkin (eds), The Labour Party in Wales 1900-2000 (Cardiff: University of Wales Press, 2000), p. 220.

124 Robert Smillie and Frank Hodges, 'Introduction', in Edgar L. Chappell and J. A. Lovat-Fraser, Pithead and Factory Baths (Cardiff: Welsh Housing and Development Association, 1920), p. vii. For a similar perspective, see 'The Miner's Lot', The Lancet, 13 August 1938, p. 408.

125 Evans and Jones, “'A Blessing for the Miner's Wife”, p. 19.

126 Evans and Jones, “'A Blessing for the Miner's Wife”', pp. 20-1.

127 For an honourable exception, see McIvor and Johnston, Miners' Lung, pp. 237-307. 